Ayah Ahmed Mohsen Mohamed

\title{
The Relationship between Corporate Ownership Structure and Earnings' Quality and its Implications for Stock Prices: An Empirical Study Ayah Ahmed Mohsen Mohamed
}

\begin{abstract}
:
This study aims to examine the relationship between the level of institutional as well as managerial ownership and the quality of reported earnings. Besides, this study aims to address the capital market consequences of this relationship by examining its impact on the firm stock price. The results have shown that higher level of managerial ownership has a significant negative impact on the quality of reported earnings. The results have also shown that higher level institutional ownership has a significant negative impact on the quality of reported earnings. Finally, the results have shown that the level of institutional ownership as well as managerial ownership has a significant indirect positive impact on the firm stock prices through its impact on the quality of reported earnings.
\end{abstract}


The Relationship between Corporate Ownership Structure and

$\sim$ Ayah Ahmed Mohsen Mohamed

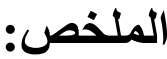

يهرف هذا البحث الى اختبار العلاقة بين ملكية الموسسات المالية و ملكية

الإداره و جوده الأرباح المحاسبية و مدى تأثثر و إنعكاس هذه العلاقة على أسعار

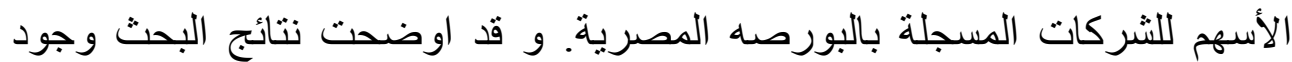

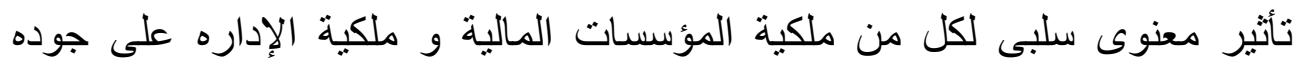
الأرباح.

كما اوضحت النتائج وجود تأثير معنوى سلبى لجوده الأرباح على أسعار

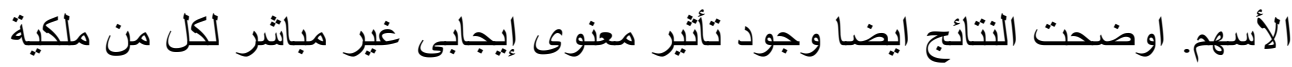

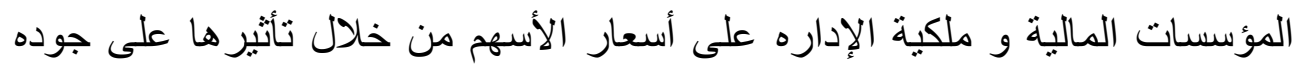
الأرباح. 
The Relationship between Corporate Ownership Structure and

Ayah Ahmed Mohsen Mohamed

\section{Introduction:}

Enhancing overall capital market efficiency relies on the quality of the financial reporting information. That is basically due to the premise that high quality financial reporting positively influences capital providers and other stakeholders in making improved, better informed investment, credit, and similar resource allocation decisions. One major dimension of financial reporting quality is the quality of reported earrings since it constitutes a premier component of firm-specific information; investors as well as financial analysts devote a great deal of attention to earnings more than any other summary measure of firm performance such as dividends and cash flows.

However, earlier in this decade corporate financial scandals in the United States and Europe like Enron, WorldCom, and Parmalat, have highlighted the willingness and ability of corporate managers to defraud investors and other stakeholders by manipulating the firm's reported earnings; given the heightened attention to accounting earnings top executives have been found to aggressively manage reported earnings, in an attempt to improve their companies' apparent performance. Accordingly, there have been growing concerns about the integrity of financial reporting practices and the extent to which reported earnings reflect firms' operating fundamentals. Earnings quality has then became a very popular topic of debate not only among academics, but also among investors, analysts, regulators, and the financial press. 
The Relationship between Corporate Ownership Structure and

Ayah Ahmed Mohsen Mohamed

Even though accounting standards were widely perceived as important determinants of the quality of reported earnings, it has been found that accounting standards alone do not determine the quality of financial reporting. Beyond accounting standards, incentives of preparers and auditors, enforcement mechanisms, ownership structure and other institutional features of the economy affect the outcome of the financial reporting process (Ball, Robin, \& Wu, 2003; Christensen, Lee, \& Walker, 2008; Soderstrom \& Sun, 2007).

From this perspective a stream of research (e.g. Warfield, Wild, \& Wild, 1995; Fan \& Wong, 2002; Francis, Schipper, \& Vincent, 2005; Wang, 2006) have come to focus on corporate ownership structure implications for various aspects of financial reporting quality across firms in many countries. The Findings of these various studies suggest that whether corporate ownership is concentrated or dispersed as well as the type of the ultimate controlling shareholder; manager, family, institution, or the government, may affect corporate managers' opportunistic behavior and the propensity to expropriate shareholders' wealth, and thus could potentially affect financial reporting quality.

However, empirical results regarding the association between different aspects of ownership structure and various attributes of financial reporting quality are mixed and there exists neither theoretical nor empirical consensus on whether ownership structure improves or reduces financial reporting quality, which indicates that the relation between ownership structure and 
The Relationship between Corporate Ownership Structure and

Ayah Ahmed Mohsen Mohamed

financial reporting quality is still an empirical issue. Besides the capital market consequences for the relationship between ownership structure and financial reporting quality specifically in developing countries still require further research.

This research attempts to contribute not only to the current debate regarding the relationship between various aspects of corporate ownership structure and financial reporting quality but also to the broader literature attempting to understand the main determinants of financial reporting quality and more specifically the quality of reported earnings. Besides, unlike most existing research that commonly examines corporate ownership structure implications for financial reporting quality in developed countries, this research focus on examining the relationship between corporate ownership structure and earnings quality in a developing country with different institutional settings. Egypt has an institutional setting similar to most continental countries, classified by Porta, et al., 1999 as French-origin civil law countries, characterized by high concentration of ownership, weak investor rights and boards which are not independent of controlling shareholders.

Furthermore this study attempts to build on prior studies by addressing the capital market consequences for the relationship between ownership structure and earnings quality by examining their impact on the firm stock price.

The remainder of this paper is organized as follows: Section 2 outlines prior literature and hypotheses tested in this 
The Relationship between Corporate Ownership Structure and

〜 Ayah Ahmed Mohsen Mohamed

paper. Section 3 outlines the research method including sample selection procedures, data sources, variables measurement, and empirical models employed. Section 4 presents data analysis, statistical techniques applied, and the main findings. Section 5 concludes by discussing the implications of the research findings, highlighting potential limitations and considering future areas for research.

\section{Literature Review and Hypotheses Development:}

\subsection{Managerial Ownership and Earnings Quality:}

Prior studies have provided mixed evidence regarding the relationship between managerial ownership and earrings quality. Evidence provided by these studies can be grouped into negative relationship, no relationship, U- shaped relationship, and positive relationship.

Warfield, Wild, \& Wild, (1995) hypothesized and consistently found a positive relationship between the level of managerial ownership and the quality of reported earnings as measured by the informativeness of earnings and the absolute value of discretionary accruals. In an attempt to interpret this relationship, they argued that because of the greater personal investment and relatively less influence from capital markets, highly invested managers are more likely to make accountings choices that reflect the firm underlying economics rather than personal motives.

In contrast to the Warfield, Wild, \& Wild, (1995) findings, Gabrielsen, Gramlich, \& Plenborg, (2002) found a negative 
The Relationship between Corporate Ownership Structure and

Ayah Ahmed Mohsen Mohamed

relationship between managerial ownership and earnings quality as proxied by earnings informativness. Consistent with the entrenchment hypotheses, they argued that management entrenchment and the resulting lack of market discipline may induce lower earnings quality among firms with high managerial ownership. Entrenched manager-shareholder may enjoy benefits other than maximizing shareholders wealth such as task shirking and perk extracting. Thereby they potentially have the incentives to pursue self interest non value-maximizing actions.

These actions may include engaging in earnings manipulation practices with direct wealth effect for management like boosting reported earnings in order to raise bonuses which could ultimately lead to lower earnings quality.

On the other hand, Yeo, Tan, Ho, \& Chen, (2002) observed a U-shaped or non linear relationship between managerial ownership and earnings quality as proxied by earnings informativness. They found that at low level of management ownership $(\leq 25 \%)$ the informativeness of earnings increases with managerial ownership supporting the convergence of interest hypothesis. However at higher levels of managerial ownership the entrenchment effect sets in and high managerial ownership negatively influences earnings informativeness.

Despite these conflicting results, the researcher hypothesizes a negative association between managerial 
The Relationship between Corporate Ownership Structure and

Ayah Ahmed Mohsen Mohamed

ownership and earnings quality. Therefore, the following hypothesis could be stated:

$\mathrm{H}_{1}$ : Managerial ownership has a significant impact on earnings quality.

\subsection{Institutional Ownership and Earnings Quality:}

Velury \& Jenkins, (2006) argued that institutional investors have both the power and incentives to encourage the reporting of high quality earnings. However whether institutional investors actually use this power and be well incentivized to encourage the reporting of high quality earnings is a function of the size of their shareholdings and investment horizons. Depending on their investment horizons and the size of their shareholdings institutional investors can either encourage opportunistic managerial behavior or actively monitor firms, thus constraining managerial discretion and improving the quality of reported earnings (Koh, 2007).

On one hand, Chung, Firth, \& Kim, (2002) argued that if institutional shareholdings are high, they will be less marketable and typically held for longer periods of time. When their shareholdings are held for the long term, institutions will be concerned about the underlying profitability of the firm and will attempt to influence top management to focus on managing shareholders' long-term interests rather than being pre-occupied with manipulating the firm's reported earnings on a year by year basis.

On the other hand when the size of their shareholdings is relatively low institutional investors can easily liquidate their 
The Relationship between Corporate Ownership Structure and

〜 Ayah Ahmed Mohsen Mohamed

investment stakes if they are dissatisfied with the management or current earnings performance, thereby there is less incentive for them to monitor the management opportunistic behavior (Chung, Firth, \& Kim, 2002). In this circumstance institutional investors are transit, short term oriented investors who are overly focused on the current earnings rather than the long run value of the firm. Such short term investment horizon and excessive focus on current earnings by transient institutional investors create incentives for firm management to opportunistically manipulate reported earnings upwards (Koh, 2003) which implies that institutional ownership is likely associated with lower earnings quality.

These arguments lead to the following hypothesis:

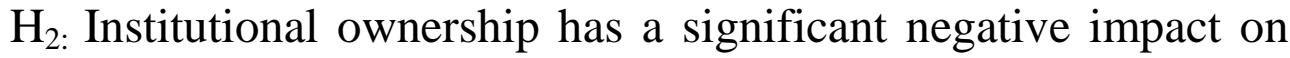
earnings quality.

\subsection{Capital Market Consequences of Earnings Quality:}

A review of prior studies addressing earnings quality implications for firm's stock prices shows that these studies have provided mixed evidence. On one hand, Balsam, Bartov, \& Marquardt (2002) predicted and consistently found evidence supporting the negative association between the degree of accruals management as an inverse indication of earnings quality and the stock price reaction around the 10-Q filing date for U.S. firms.

Thereby suggesting that, investors reassess reported quarterly earnings figures using other financial statement 
The Relationship between Corporate Ownership Structure and

〜 Ayah Ahmed Mohsen Mohamed

information and that this reassessment is associated with a substantial stock price change. In turn the extent to which earnings reflect the firm underlying performance could potentially lead to higher market valuation.

On the other hand, Kasznik \& Mcnichols, (2002) found evidence that, firms engaging in earnings manipulation practices to meet or beat prior period earnings targets or analyst expectations are rewarded with higher market valuations, and that they are likely to suffer significant stock price declines otherwise.

Thereby suggesting that when reported earnings meet the expectations investors still might not recognize and respond to the presence of earnings manipulations that erodes the quality of reported earnings.

Dechow, Ge , \& Schrand, (2010) provided several explanations for this combination of conflicting results regarding the market valuation consequences for earnings quality.

One possible explanation is that the market rewards some types of earnings manipulation practices and not others.

Another explanation is the greater market mispricing of less transparent earnings manipulation practices.

Based on the above discussion the third and fourth hypotheses could be stated as follows:

$\mathrm{H}_{3}$ : Earnings quality has a significant positive impact on stock prices. 
The Relationship between Corporate Ownership Structure and

〜Ayah Ahmed Mohsen Mohamed

$\mathrm{H}_{4}$ : Corporate ownership structure has a significant negative impact on stock prices through its impact on earnings quality

$\mathrm{H}_{4 \mathrm{a}}$ : Institutional ownership has a significant negative impact on stock prices through its impact on earnings quality.

$\mathrm{H}_{4 \mathrm{~b}}$ : Managerial ownership has a significant negative impact on stock prices through its impact on earnings quality.

\section{Research Method:}

\subsection{Sample Selection:}

The selected sample is comprised of 56 publicly listed firms in the Egyptian Exchange during a five year sample period (2008-2012). Consistent with extent literature, the sample excludes financial services companies (e.g. banks and insurance companies) as their reported earnings as well as cash flows from operations differ dramatically from other firms. Besides they are subject to different disclosure requirements that make estimating the quality of reported earnings problematic. Firms with non December 31 fiscal year-end are as well excluded in order to control for the effects of common market-based economic factors. It will facilitate interpretation of results in the context of the economics of the period.

The sample also excludes firms with insufficient data to calculate any of the independent variables. Finally, the modified Dechow-Dichev model employed to measure the quality of reported earnings require the availability of cash flow data for 1 year before and after theselected period (i.e., 2008 and 2012) thereby the sample is restricted to firms with at least 7 years of 
The Relationship between Corporate Ownership Structure and

〜 Ayah Ahmed Mohsen Mohamed

data. The sample selection procedures as well as the final sample size are summarized in Table (3.1).

\section{Table 3.1:}

Sample Description

\section{Sample Selection Procedure}

\begin{tabular}{ll}
\hline Total number of public actively traded firms listed & 180 \\
on the Egyptian exchange & \\
Less: & 43 \\
Banks and other financial services firms & \\
Firms with insufficient data to estimate residuals & 44 \\
from the modified Dechow-Dichev model or to & \\
compute control variables & 23 \\
Firms with non-December 31 fiscal year end & 14 \\
Firms trading in foreign currency. & 56 \\
\hline Total sample size &
\end{tabular}

\subsection{Data Sources:}

The financial statement data used to estimate earnings quality measure are obtained from the Egyptian Company for Information Dissemination (EGID). Data on Institutional and managerial ownership as well as stock prices were also obtained from the Egyptian Company for Information Dissemination (EGID) as well as the Annual Disclosure Book.

\subsection{Variables Measurement:}

\subsubsection{Measuring Institutional Ownership:}

Consistent with Koh (2007) , institutional ownership (denoted as INST ) is measured as the total number of shares held by institutional investors including insurance companies (life and non-life), pension funds, investment trusts, and financial 
The Relationship between Corporate Ownership Structure and

〜 Ayah Ahmed Mohsen Mohamed

institutions (including banks and finance companies) divided by the total number of outstanding shares.

\subsubsection{Measuring Managerial Ownership:}

Managerial ownership (denoted as MGR) is calculated as the percentage of outstanding shares held by executive directors and the board members.

\subsubsection{Measuring Earnings Quality:}

Earnings' quality is a multidimensional concept that has no universally accepted measure. The researcher employs an accruals quality measure based on the cross sectional Dechow and Dichev (2002) model, as modified by Francis, et al., (2005). Compared to other measures of accruals quality, the Dechow and Dichev (2002) measure does not rely solely on earnings management or assumptions related to market efficiency (e.g., value-relevance).

This measure can capture both biased "discretionary" accruals that arises from incentives to manage earnings and unintentionally poorly estimated accruals that arises from management lapses and environmental uncertainty.

The Dechow-Dichev measure defines the quality of accruals in terms of the strength of the relation between current accruals and past, present, and future cash flows. The theoretical development of this measure as presented by Dechow and Dichev (2002) is that Accruals are estimates of noncash earnings 
The Relationship between Corporate Ownership Structure and

$\sim$ Ayah Ahmed Mohsen Mohamed

resulting from timing differences between the provision or consumption of goods and services and the receipt or disbursement of cash. These Accruals reverse once the associated cash is received or disbursed.

Accordingly, low accruals quality is captured by the uncertainty associated with the accrual-to-cash flow mapping. Specifically, the proxy for accruals and earnings quality is measured by estimating the following model:

$\mathrm{TCA}_{\mathrm{j}, \mathrm{t}}=\mathrm{a}_{0}+\mathrm{a}_{1} \mathrm{CFO}_{\mathrm{j}, \mathrm{t}-1}+\mathrm{a}_{2} \mathrm{CFO}_{\mathrm{j}, \mathrm{t}}+\mathrm{a}_{3} \mathrm{CFO}_{\mathrm{j}, \mathrm{t}+\mathbf{1}}+\mathrm{a}_{4} \Delta \mathrm{REV}_{\mathrm{j}, \mathrm{t}}+\mathrm{a}_{5} \mathrm{PPE}_{\mathrm{j}, \mathrm{t}}+$ $\varepsilon_{\mathrm{j}, \mathrm{t}}$ eq(1)

Where:

$\mathbf{T C A}_{\mathrm{j}, \mathrm{t}}=$ total current accruals measured as $\left(\mathrm{NIBE}_{\mathrm{i}, \mathrm{t}}-\mathrm{CFO}_{\mathrm{i}, \mathrm{t}}+\mathrm{DEPN}_{\mathrm{i}, \mathrm{t}}\right)$

$\mathrm{NIBE}_{\mathrm{j}, \mathrm{t}}=$ net income before extraordinary items at year $\mathrm{t}$ for firm $\mathbf{j}$

$\operatorname{DEPN}_{\mathrm{j}, \mathrm{t}}=$ depreciation and amortization expense at year $\mathbf{t}$ for firm $\mathbf{j}$.

$\mathrm{CFO}_{\mathrm{j}, \mathrm{t}}=$ cash flow from operations at year $\mathrm{t}$

$\mathrm{CFO}_{\mathrm{j}, \mathrm{t}-1}=$ cash flow from operations at year $\mathrm{t}-1$

$\mathrm{CFO}_{\mathrm{j}, \mathrm{t}+1}=$ cash flow from operations at year $\mathrm{t}+\mathbf{1}$

$\Delta R E V_{j, t}=$ annual change in sales revenues of firm $j$ between years $t$ and $t-1$ $\mathbf{P P E}_{\mathrm{j}, \mathrm{t}}=$ growth value of property planet and equipment of firm $\mathbf{j}$ in year $t$ $\varepsilon_{\mathrm{j}, \mathrm{t}}=$ error term (residual)

Residuals from Equation (1) represent the estimation errors in the current accruals that are not associated with operating cash flows and that cannot be explained by the change in revenue and the level of PPE. Francis, et al., (2005) had used the standard deviation of the residuals as an inverse measure of earnings quality for each firm where larger standard deviation of residuals indicates poorer accruals and earnings quality.

However given the short longitudinal time frame in the study and the need to capture this measure on firm-year basis, the 
The Relationship between Corporate Ownership Structure and

〜 Ayah Ahmed Mohsen Mohamed

researcher follows Srinidhi and Gul (2007) and uses the absolute value of this residual as a proxy for earnings quality; the higher the absolute residual for each sample company, the lower is the quality of earnings.

Consistent with Hope, Thomas, \& Vyas, (2013) the researcher then multiplies the absolute values of the modified Dechow- Dichev measure by negative one so that higher values represent higher earnings quality.

\subsection{Model Specifications for Hypothesis Testing}

First: Corporate Ownership Structure and Earnings Quality:

To test the impact of corporate ownership structure on earnings quality the following regression model is estimated:

$\mathrm{EQ}_{\mathrm{j}, \mathrm{t}}=\mathbf{b}_{\mathbf{0}}+\mathrm{b}_{1} \mathrm{INST}_{\mathrm{j}, \mathrm{t}}+\mathrm{b}_{2} \mathrm{MGR}_{\mathrm{j} . \mathrm{t}}+\mathrm{b}_{3} \mathrm{SIZE}_{\mathrm{j}, \mathrm{t}}+\mathbf{b}_{\mathbf{4}} \mathrm{ROA}_{\mathrm{j}, \mathrm{t}}+\mathbf{b}_{5}$ LEV $_{\mathrm{j}, \mathrm{t}}+\mathrm{b}_{6}$ GROWTH $_{\mathrm{j}, \mathrm{t}}+\mathrm{b}_{7}$ LOSS $_{\mathrm{j}, \mathrm{t}}+\varepsilon_{\mathrm{j}, \mathrm{t}} \ldots \ldots \ldots \ldots \ldots \ldots \ldots . . . . . . .(2)$

Where:

$\mathrm{EQ}_{\mathrm{j}, \mathrm{t}}=$ earnings quality measured as the absolute value of the residuals estimated from eq(1).

INST $_{\mathrm{j}, \mathrm{t}}=$ institutional ownership at $\mathrm{t}$, measured by the percentage of total common equity owned by institutions.

MGR $_{\mathrm{j}, \mathrm{t}}=$ managerial ownership, measured by the percentage of total common equity owned by managers and directors.

$\operatorname{SIZE}_{\mathrm{j}, \mathrm{t}}=$ natural $\log$ of total assets at $\mathbf{t}$ for firm $\mathbf{j}$

$\mathbf{R O A}_{j, t}=$ net income at $\mathbf{t}$ divided by average total assets at $\mathbf{t}$

$\mathrm{LEV}_{\mathrm{j}, \mathrm{t}}=$ firm leverage at $\mathrm{t}$, measured by total liabilities divided by total assets

GROWTH $_{\mathrm{j}, \mathrm{t}}=$ growth rate in sales at $\mathrm{t}$, maesured as the sales in year $t$ minus sales in year $t-1$ and scaled by sales in year $t-1$. 
The Relationship between Corporate Ownership Structure and

〜 Ayah Ahmed Mohsen Mohamed

$\mathbf{L O S S}_{\mathrm{j}, \mathrm{t}}=$ dummy variable takes the value of one if net income $<0$, and zero otherwise

$\varepsilon_{\mathrm{j}, \mathrm{t}}=$ error term (residual).

Given that corporate ownership structure is unlikely to be the sole determinant of managers' accounting choices and earnings' quality, several control variables were included to proxy for several factors that have been shown to be associated with the quality of reported earnings in the existing literature. These control variables are as follows:

Firm size:

Ball \& Shivakumar (2005), have found evidence that firm size significantly influence the quality of reported earnings where larger firms tend to report higher quality earnings than small firms since they are subject to greater litigation risk.

Growth:

Growth is another factor that could potentially negatively influence earnings quality given that growth companies are generally more willing to engage in income increasing earnings management in order to increase the value of their shares and attract more investors to meet their capital needs (Houqe, Zijl, Dunstan, \& Karim, 2012).

Leverage:

Firm leverage is an increasingly influential factor that could either negatively or positively affect earnings' quality. On one hand Companies that are closer to breaking their debt covenants are more willing to engage in earnings increasing accruals. Thereby firm leverage could be negatively related to the 
The Relationship between Corporate Ownership Structure and

〜 Ayah Ahmed Mohsen Mohamed

quality of reported earnings. On the other hand since high leveraged firms are subject to greater scrutiny by debt-holders who have the incentive to monitor managers' behavior, high leveraged firms are likely to provide high quality reported earnings and thereby firm leverage could be positively related to the quality of reported earnings.

Loss:

Consistent with Wang (2006), a dummy variable is used for firms with losses as a proxy for financial distress and bankruptcy risk as they are potential incentives for manipulating reported earnings.

ROA:

ROA as a proxy for profitability and firm performance is an important factor affecting the quality of reported earnings. Consistently, Lee, Li, \& Yue, (2006) have argued that eliminating the effect of performance may result in a biased measure.

\section{Second: Earnings quality, and Stock Prices:}

To test the impact of earnings quality on the firm stock prices the following regression model is estimated:

$\mathrm{Sp}_{\mathrm{j}, \mathrm{t}}=\mathrm{c}_{\mathbf{0}}+\mathrm{c}_{1} \mathrm{EQ}_{\mathrm{j}, \mathrm{t}}+\mathrm{c}_{2} \operatorname{SIZE}_{\mathrm{j}, \mathrm{t}}+\mathrm{c}_{3} \mathrm{LEV}_{\mathrm{j}, \mathrm{t}}+\mathrm{c}_{4} \mathrm{LOSS}_{\mathrm{j}, \mathrm{t}}+$

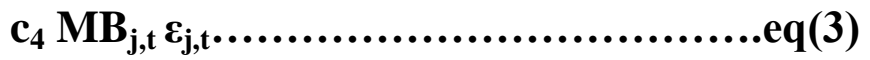

Where:

$\mathrm{Sp}_{\mathrm{j}, \mathrm{t}}$ : closing stock price on December 31 fiscal year end $\mathbf{M B}_{\mathrm{j}, \mathrm{t}}$ : market to book value ratio

All other variables are previously defined.

Consistent with prior literature (e.g. Ogneva, 2012; Callen, Khan, \& Lu, 2013) several control variables were 
The Relationship between Corporate Ownership Structure and

$\sim$ Ayah Ahmed Mohsen Mohamed

included in the model to control for their effect on the firm stock prices.

\subsection{Data Analysis and Results:}

\subsubsection{Descriptive Statistics:}

Descriptive statistics for all variables included in eq (1) that is used for estimating earnings quality are reported in table (3.2), panel A. panel B of table (3.2) provides descriptive statistics for earnings quality (EQ), Institutional ownership (INST), Managerial ownership (MGR), stock prices and other control variables included in eq (2) and eq (3).

\section{Table 3.2:}

Descriptive Statistics

\begin{tabular}{cccccc}
\hline Panel A & & & & & \\
\hline Variable & Mean & Medium & Maximum & Minimum & $\begin{array}{c}\text { Std. } \\
\text { dev }\end{array}$ \\
\hline TCA & 0.164 & 0.021 & 8.654 & -0.727 & 0.972 \\
CFOt-1 & 0.097 & 0.059 & 5.588 & -0.470 & 0.355 \\
CFOt & 0.077 & 0.060 & 0.770 & -0.941 & 0.159 \\
CFOt+1 & 0.085 & 0.059 & 0.791 & -0.550 & 0.152 \\
$\Delta$ REV & 0.010 & 0.021 & 5.877 & -8.265 & 0.775 \\
PPE & 0.412 & 0.364 & 1.410 & 0.000 & 0.351 \\
\hline
\end{tabular}

Panel B

\section{Variable Mean Medium Maximum Minimum}

Std.

\begin{tabular}{cccccc} 
& & & & & dev \\
\hline SP & 43.99 & 17.26 & 803.1 & 0.780 & 103.3 \\
EQ & -0.36 & -0.19 & -0.003 & -7.74 & 0.840 \\
INST & 8.849 & 2.230 & 66.77 & 0 & 13.72 \\
\hline
\end{tabular}


The Relationship between Corporate Ownership Structure and

〜 Ayah Ahmed Mohsen Mohamed

\begin{tabular}{cccccc}
\hline MGR & 12.54 & 0.702 & 87.12 & 0 & 21.62 \\
SIZE & 8.931 & 8.876 & 10.53 & 7.291 & 0.695 \\
ROA & 0.084 & 0.067 & 0.594 & -0.29 & 0.099 \\
LEV & 0.538 & 0.352 & 40.91 & 0.000 & 2.437 \\
GROWTH & 3.753 & 0.053 & 698.9 & -1.00 & 44.72 \\
LOSS & 0.100 & 0 & 1 & 0 & 0.300 \\
\hline
\end{tabular}

As shown in table (3.2), panel $B$ the Mean value of institutional ownership is $8.8 \%$ while the mean value of managerial ownership is $12.5 \%$ which indicates that on average the sample firms has higher managerial ownership than institutional ownership. The Mean (median) firm size as measured by natural log of total assets is 8.93 (8.88) which approximately match a total asset size of 250 million suggesting that the sample is comprised of mainly medium-to-large sized firms. On average the sample firms are profitable, with a mean ROA of 0.08 .

\subsubsection{Collinearity Statistics:}

Variance inflation factor analysis is conducted in order to test whether there is a multicollinearity problem among the independent variables included in either eq (2) or eq (3).

Table 3.3:

Variance Inflation Factor (VIF)

\begin{tabular}{ccc}
\hline Panel A & & \\
\hline Variable & Tolerance & Centered VIF \\
\hline INST & 0.935941 & 1.068443 \\
MGR & 0.938289 & 1.065769 \\
SIZE & 0.952225 & 1.050171 \\
ROA & 0.881890 & 1.133928 \\
\hline
\end{tabular}


The Relationship between Corporate Ownership Structure and

Ayah Ahmed Mohsen Mohamed

\begin{tabular}{ccc}
\hline LEV & & \\
GROWTH & 0.950153 & 1.052461 \\
LOSS & 0.904043 & 1.106141 \\
Panel B & 0.795133 & 1.257650 \\
\hline Variable & & \\
\hline EQ & Tolerance & Centered VIF \\
SIZE & $\mathbf{0 . 9 5 8 1 0 0}$ & $\mathbf{1 . 0 4 3 7 3 2}$ \\
LEV & $\mathbf{0 . 9 4 6 3 2 0}$ & $\mathbf{1 . 0 5 6 7 1 7}$ \\
LOSS & $\mathbf{0 . 9 9 7 4 5 3}$ & $\mathbf{1 . 0 0 2 5 5 3}$ \\
MB & $\mathbf{0 . 9 9 0 3 7 1}$ & $\mathbf{1 . 0 0 9 7 2 2}$ \\
\hline
\end{tabular}

As shown in table (3.3), Collinearity diagnostics performed using the variance inflation factors (VIF) indicates that there is no multicollinearity problem that could affect the regression results reported later, given that all centered VIF values are less than 5 and tolerance values are greater than 0.20. Panel A of table (3.4) shows the variance inflation factors for independent variables included in eq (2) while panel B of table (3.3) variance inflation factors for independent variables included in eq (3).

\subsubsection{Multivariate Analysis:}

Table (3.4) presents the results of estimating the Dechow and Dichev (2002) model as modified by Francis J. , LaFond, Olsson, \& Schipper (2005) using pooled ordinary least squares (OLS).

\section{Table 3.4:}

Regression Estimates of the Modified Dechow and Dichev (2002) Model of Accrual Quality.

$$
\begin{aligned}
& \mathrm{TCA}_{\mathrm{j}, \mathrm{t}}=\mathrm{a}_{0}+\mathrm{a}_{1} \mathrm{CFO}_{\mathrm{j}, \mathrm{t}-1}+\mathrm{a}_{2} \mathrm{CFO}_{\mathrm{j}, \mathrm{t}}+\mathrm{a}_{3} \mathrm{CFO}_{\mathrm{j}, \mathrm{t}+1}+\mathrm{a}_{4} \Delta \mathrm{REV} \mathrm{j}_{\mathrm{j}, \mathrm{t}}+\mathrm{a}_{5} \\
& \mathrm{PPE}_{\mathrm{j}, \mathrm{t}}+\varepsilon_{\mathrm{j}, \mathrm{t}}
\end{aligned}
$$


The Relationship between Corporate Ownership Structure and

〜 Ayah Ahmed Mohsen Mohamed

\begin{tabular}{ccccc}
\hline \hline Variable & Coefficient & Std error & t-statistic & p-value \\
\hline Intercept & $\mathbf{- 0 . 1 5 7 6 7 8}$ & $\mathbf{0 . 0 1 1 3 4 0}$ & $\mathbf{- 1 3 . 9 0 4 5 7}$ & $\mathbf{0 . 0 0 0 0} * * *$ \\
CFOt-1 & $\mathbf{0 . 0 4 5 2 2 8}$ & $\mathbf{0 . 0 2 1 9 6 8}$ & $\mathbf{2 . 0 5 8 8 3 2}$ & $\mathbf{0 . 0 3 9 5} * *$ \\
CFOt & $\mathbf{- 1 . 1 6 8 6 6 4}$ & $\mathbf{0 . 0 5 2 3 8 8}$ & $\mathbf{- 2 2 . 3 0 7 9 0}$ & $\mathbf{0 . 0 0 0 0} * * *$ \\
CFOt+1 & $\mathbf{- 0 . 1 8 8 9 9 8}$ & $\mathbf{0 . 0 5 4 4 5 6}$ & $\mathbf{- 3 . 4 7 0 6 6 9}$ & $\mathbf{0 . 0 0 0 5} * * *$ \\
DREV & $\mathbf{0 . 0 0 9 9 0 0}$ & $\mathbf{0 . 0 0 9 5 4 0}$ & $\mathbf{1 . 0 3 7 7 5 7}$ & $\mathbf{0 . 2 9 9 4}$ \\
PPE & $\mathbf{1 . 0 2 8 2 6 6}$ & $\mathbf{0 . 0 2 4 0 3 6}$ & $\mathbf{4 2 . 7 8 0 9 9}$ & $\mathbf{0 . 0 0 0 0} * * *$ \\
\hline \hline
\end{tabular}

Cross sections included

$\mathbf{R}^{2}$

$\mathbf{0 . 1 1 4}$

No. of observations

Adjusted $\mathbf{R}^{2}$

0.114

F-statistic 403.1

No. of observations(after

p-value (F-statistic)

0.00 adjustments)

56

280

279

Total pool (balanced)

observations

15324

Notes: Reported p-value is 2-tailed. *** And ** Represent significance at the 1 percent, and 5 percent levels, respectively.

Consistent with Dechow and Dichev (2002) the coefficient of the current period cash flow (CFO), is negative $(-1.168664)$ while the coefficient of previous period cash flow $\left(\mathrm{CFO}_{\mathrm{t}-1}\right)$ is positive (0.045228) which indicates that total current accruals (TCA) is negatively affected by current period cash flows and positively affected by previous period cash flows.

Consistent with Srinidhi \& Gul, (2007) the coefficient of property plant and equipment (PPE) (1.028266) as well as the change of revenues $(\Delta \mathrm{REV})$ is positive (0.009900) which indicates that higher changes in revenue and higher levels of PPE potentially leads to higher total current accruals and that is basically due to the premise that firms with higher gross PPE are likely to be firms with high assets-in-place and, therefore, are more likely to have higher current accounting accruals. All 
The Relationship between Corporate Ownership Structure and

〜 Ayah Ahmed Mohsen Mohamed

independent variables in the model except for $(\triangle \mathrm{REV})$ are significantly associated with (TCA) at 1 percent and 5 percent significant level ( $\mathrm{p}$-value $<0.01$, p- value $<0.05$ ), and the model is also significant at 1 percent level ( $\mathrm{p}$ - value $<0.01$ ) with an adjusted $\mathrm{R}^{2}$ of 0.114 which indicates that the model explains $11.4 \%$ of variations in total current accruals (TCA).

\section{Table 3.5:}

Regression of Earnings Quality on Institutional Ownership, Managerial Ownership, and other Control Variables

EQj,t = b0+ b1 INSTj,t + b2 MGRj.t +b3 SIZEj,t + b4 ROAj,t + b5 LEVj,t + b6 GROWTHj,t + b7 LOSSj,t + عj,t

\begin{tabular}{|c|c|c|c|c|}
\hline Variable & Coefficient & Std error & t-statistic & p-value \\
\hline Intercept & -1.927476 & 0.076655 & -25.14479 & $0.0000 * * *$ \\
\hline INST & -0.004862 & 0.000316 & -15.38438 & $0.0000 * * *$ \\
\hline MGR & -0.003081 & 0.000171 & -18.03607 & $0.0000 * * *$ \\
\hline SIZE & 0.188874 & 0.008427 & 22.41201 & $0.0000 * * *$ \\
\hline ROA & -0.457613 & 0.032722 & -13.98472 & $0.0000 * * *$ \\
\hline LEV & 0.002786 & 0.000873 & 3.192556 & $0.0014 * * *$ \\
\hline GROWTH & -0.000225 & 0.000000 & -4.618424 & $0.0000 * * *$ \\
\hline LOSS & -0.106118 & 0.009746 & -10.88857 & $0.0000 * * *$ \\
\hline $\begin{array}{l}\mathbf{R}^{2} \\
\end{array}$ & 0.767 & \multicolumn{2}{|c|}{ Cross sections included } & 56 \\
\hline Adjusted $\mathbf{R}^{2}$ & 0.766 & \multicolumn{2}{|c|}{ No. of observations } & 280 \\
\hline F-statistic & 5569.5 & \multicolumn{2}{|c|}{$\begin{array}{l}\text { No. of observations(after } \\
\text { adjustments) }\end{array}$} & 272 \\
\hline $\begin{array}{l}\text { p-value(F- } \\
\text { statistic) }\end{array}$ & 0.000 & \multicolumn{2}{|c|}{$\begin{array}{l}\text { Total pool (balanced) } \\
\text { observations }\end{array}$} & 15232 \\
\hline
\end{tabular}

Notes: Reported p-value is 2-tailed. ***Represent significance at the 1 percent level Table 3.5 presents the results 
The Relationship between Corporate Ownership Structure and

Ayah Ahmed Mohsen Mohamed

of estimating Equation (2) using pooled ordinary least squares (OLS).

The coefficient of institutional ownership (INST) as well as managerial ownership (MGR) is negative (-0.004862 and 0.003081 respectively) which indicates that firms with higher level of institutional and insider ownership reports low quality earnings thereby supporting $\mathrm{H}_{1 \mathrm{a}}$ and $\mathrm{H}_{1 \mathrm{~b}}$. Consistent with Ball \& Shivakumar (2005), the coeffient of firm size (SIZE) is positive (0.188874) which indicates that larger firms reports higher quality earnigs and that is potentially due to being subject to greater media and public scrutiny. The negative coefficient of the return on assets (ROA) (-0.457613) indicates that highly profitable firms report low quality earnings.

The coefficient of the firm leverage (LEV) is positive (0.002786) which indicates that high leverage firms provide high quality reported earnings thereby supporting the notion that highly leveraged firms face control from debt-holders who have the incentive to monitor managers' opportunistic behavior. Consistent with Hope, Thomas, \& Vyas, (2013) the coefficient of the firm growth (GROWTH) and firm losses (LOSS) is negative $(-0.000225,-0.106118)$ which indicates that growth firms as well as those reporting losses are more likely to report low quality earnings.

All independent variables in the model are significantly associated with earnings quality (EQ) at 1 percent significant level ( $p$ - value $<0.01$ ) and the model is also significant at the 
The Relationship between Corporate Ownership Structure and

〜 Ayah Ahmed Mohsen Mohamed

same level with an adjusted $\mathrm{R}^{2}$ of 0.7669 which indicates that the model explains $76.69 \%$ of variations in earnings quality (EQ).

Table 3.6:

Regression of Stock Prices on Earnings Quality and Control Variables

\begin{tabular}{|c|c|c|c|c|}
\hline \multicolumn{5}{|c|}{$\mathrm{Sp}_{\mathrm{j}, \mathrm{t}}=\mathrm{c}_{0}+\mathrm{c}_{1} \mathrm{EQ}_{\mathrm{j}, \mathrm{t}}+\mathrm{c}_{2} \mathrm{SIZE}_{\mathrm{j}, \mathrm{t}}+\mathrm{c}_{3} \mathrm{LEV}_{\mathrm{j}, \mathrm{t}}+\mathrm{c}_{4} \mathrm{LOSS}_{\mathrm{j}, \mathrm{t}}+\mathrm{c}_{5} \mathrm{MB}_{\mathrm{j}, \mathrm{t}}+\varepsilon_{\mathrm{j}, \mathrm{t}}$} \\
\hline Variable $\quad$ Co & oefficient & Std error & t-statistic & p-value \\
\hline Intercept & $\mathbf{1 0 9 . 8 5 7 0}$ & 13.74419 & -7.992977 & $0.0000 * * *$ \\
\hline EQ & 8.432705 & 1.241788 & -6.790776 & $0.0000 * * *$ \\
\hline SIZE & 15.17488 & 1.515264 & 10.01468 & $0.0000 * * *$ \\
\hline LEV & 0.977780 & 0.215941 & 4.527997 & $0.0000 * * *$ \\
\hline LOSS & 31.23040 & 1.943340 & -16.07048 & $0.0000 * * *$ \\
\hline MB & 10.15191 & 0.183523 & 55.31691 & $0.0000 * * *$ \\
\hline \multirow{6}{*}{$\begin{array}{l}\mathbf{R}^{2} \\
\text { Adjusted } \mathbf{R}^{2} \\
\text { F-statistic } \\
\text { p-value (F-statistic) }\end{array}$} & \multirow{6}{*}{\begin{tabular}{|c|}
0.460 \\
0.459 \\
2202.6 \\
0.000
\end{tabular}} & \multicolumn{2}{|c|}{ Cross sections included } & 56 \\
\hline & & \multicolumn{2}{|c|}{ No. of observations } & 280 \\
\hline & & \multicolumn{2}{|c|}{ No. of observations } & \\
\hline & & & \\
\hline & & \multicolumn{2}{|c|}{277} & \\
\hline & & \multicolumn{2}{|c|}{$\begin{array}{l}\text { Total pool (balanced) } \\
\text { observations }\end{array}$} & 15512 \\
\hline
\end{tabular}

Notes: Reported p-value is 2-tailed. *** Represent significance at the 1 percent level.

Table 3.6 presents the results of estimating Equation (3) using pooled ordinary least squares (OLS). As shown in Table 3.6 the coefficient of earnings quality (EQ) is negative ($8.432705)$ and significant at $\mathrm{p}$-value $<0.001$ which indicates that the quality of reported earnings significantly negatively affect the firm stock prices which is inconsistent with $\mathrm{H}_{2}$. 
The Relationship between Corporate Ownership Structure and

Ayah Ahmed Mohsen Mohamed

The coefficient of the firms size (SIZE) is positive (15.17488) and significant at p-value $<0.001$ which indicates that large size firms have higher stock prices. The coefficient of firm losses (LOSS) is negative (-31.23040) and significant at pvalue $<0.001$ thereby indicating that firms reporting losses have low stock prices.

The model is significant at p-value $<0.001$ with an adjusted $\mathrm{R}^{2}$ of $45.99 \%$ which indicates that the model explains $45.99 \%$ of variations in the firm stock prices (SP).

\subsubsection{Path Analysis:}

The researcher employs path analysis embedded in a structural equation model in order to examine the hypothesized indirect effect of institutional as well as managerial ownership on the firm stock prices through its impact on the quality of reported earnings.

Path analytical models tested within structural equation modeling software are widely used in many disciplines because they enable researchers to examine direct and indirect effects while explicitly taking into account measurement errors in both, dependent and independent variables, as well as estimating the magnitude and strength of these effects within a hypothesized causal system (Kline \& Klammer, 2001).

The recursive path model is shown in Figure (1).

As shown in the figure, directed (i.e., single-headed) arrows represent a causal relationship. The endogenous variables 
The Relationship between Corporate Ownership Structure and

〜 Ayah Ahmed Mohsen Mohamed

are distinguished from the exogenous variables by having directed arrows pointing towards them, while exogenous variables appear only at the tails of directed arrows. $\mathrm{e}_{1}$ and $\mathrm{e}_{2}$ are residuals or error terms, also called structural disturbances; they represent exogenous independent variables that are not directly measured and reflect unspecified causes of variability in the outcome or unexplained variance plus any error due to measurement.

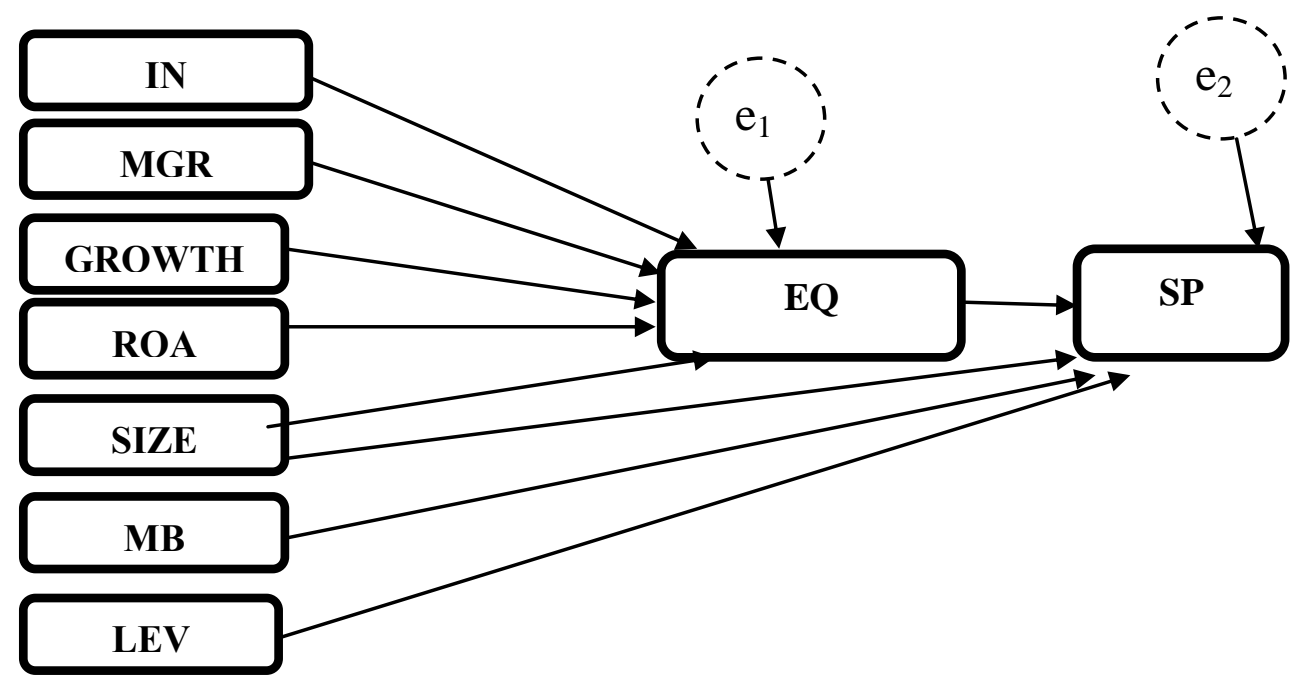

Figure 1: A recursive path analysis model

\subsubsection{Structural Equations:}

A recursive path model can be specified by a series of path or structural equations that describe the direct causal relationships between variables. As shown in figure (1) each path variable (earnings quality, stock prices) is estimated with respect to anumber of independent variables as well as control variables selected based on prior literature. In the recursive setting, 
The Relationship between Corporate Ownership Structure and

〜 Ayah Ahmed Mohsen Mohamed

institutional ownership (INST) and managerial ownership (MGR) are determinants of earnings quality but earnings quality is not an explanatory variable to institutional ownership (INST) and managerial ownership (MGR). The same applies for stock prices where earnings quality is a determinant for stock prices while stock prices are not a determinant of earnings quality. All variables in the following equations are previously defined.

Earnings Quality Equation

The following equation is adopted to estimate earnings quality:

$$
\begin{aligned}
\mathrm{EQ}= & \mathrm{a}_{0}+\mathrm{a}_{1} \text { INST }+\mathrm{a}_{2} \text { MGR }+\mathrm{a}_{3} \text { SIZE }+\mathrm{a}_{4} \mathrm{ROA}+\mathrm{a}_{5} \mathrm{LEV}+ \\
& \mathrm{a}_{6} \text { GROWTH }+\varepsilon_{1} \ldots \ldots \ldots \ldots \text {.eq }(4)
\end{aligned}
$$

Equation (4) shows that earnings quality is affected by the level of managerial (MGR) and institutional ownership (INST) as well as those determinants identified in prior studies including the firm size (SIZE), return on assets (ROA), leverage (LEV), and growth (GROWTH ).

Stock Price Equation The following equation is adopted to estimate the firm stock prices:

$\mathrm{Sp}=\mathrm{b}_{0}+\mathrm{b}_{1} \mathrm{EQ}+\mathrm{b}_{2} \mathrm{SIZE}+\mathrm{b}_{3} \mathrm{LEV}+\mathrm{b}_{4} \mathrm{MB}+\varepsilon_{2} \ldots \ldots \ldots . . \mathrm{eq}(5)$

Equation (5) shows that stock prices is determined by earnings quality (EQ) as well as the firm size (SIZE), leverage (LEV), and market to book value ratio (MB).

\subsubsection{Model Fit}

Table (3.7) presents various measures of fit for the recursive path analysis models including the Comparative Fit 
The Relationship between Corporate Ownership Structure and

〜 Ayah Ahmed Mohsen Mohamed

Index (CFI), the Root Mean Square Error of Approximation (RMSEA), Incremental Fit Index (IFI), Chi-Square (CMIN), Relative Chi-Square, also called Normed Chi-Square computed as Chi-Square divided by the Degree of Freedom (CMIN/DF), and Normed Fit Index (NFI).

\section{Table 3.7:}

Fit Summary for Recursive Path Analysis

\section{Goodness of fit criteria}

\begin{tabular}{cc}
\hline CFI & 0.628 \\
RMSEA & 0.086 \\
IFI & 0.668 \\
CMIN, P-value & $\mathbf{8 2 . 1 9 6 , 0 . 0 0 0}$ \\
CMIN/DF & 3.044 \\
NFI & 0.575 \\
\hline
\end{tabular}

A CFI value that approaches 1 is an indicator of a good fit (Bentler , 1990). As shown in table 3.8 the CFI value is 0.628 thereby indicating a moderately good fit. RMSEA values approaching 0 with either 0.05 or 0.08 indicates a very good fit (Thompson, 2000). As sown in table 3.8, RMSEA value is 0.086 which indicates an acceptable fit. IFI values approaching 1 are considered excellent fits and values over 0.90 are adequate fits (Bollen, 1989).

As shown in table 3.8 the IFI value is 0.668 which indicates a very good fit. Normed Chi-Square value that ranges between 2 and 5 indicates a good fit.

As shown in table 3.8, the Normed Chi-Square value is 3.044 which indicate a reasonable fit. Finally an NFI value 
The Relationship between Corporate Ownership Structure and

〜 Ayah Ahmed Mohsen Mohamed

commonly ranges between 0 and 1 with higher values indicating better fit (Bentler, 1992). Accordingly, as shown in table 3.8, an NFI value of 0.575 indicates a good fit. Overall a comparison of all fit indices with their corresponding suggested values provides evidence of a good model fit.

\subsubsection{Recursive Path Analysis Results:}

Table (3.8) reports the standardized path coefficients and significance levels. Table (3.9) decomposes the total standardized effect of institutional ownership (INST) and managerial ownership (MGR) on the firm stock prices into direct and indirect effect.

\section{Table 3.8:}

Results for Recursive Path Analysis

\section{Panel A: Earnings Quality Equation}

$\mathrm{EQ}=\mathrm{a}_{0}+\mathrm{a}_{1}$ INST $+\mathrm{a}_{2}$ MGR $+\mathrm{a}_{3} \mathrm{SIZE}+\mathrm{a}_{4} \mathrm{ROA}+\mathrm{a}_{5} \mathrm{GROWTH}+\varepsilon_{1}$

\begin{tabular}{|c|c|c|c|}
\hline & $\begin{array}{c}\text { Standardized } \\
\text { coefficient }\end{array}$ & $\begin{array}{c}\text { Standard } \\
\text { error }\end{array}$ & p-value \\
\hline Intercept & -0.817 & 0.256 & $0.001 * * *$ \\
\hline INST & -0.117 & 0.141 & $0.035 * *$ \\
\hline MGR & -0.24 & 0.039 & $0.000 * * *$ \\
\hline SIZE & 0.091 & 0.012 & 0.103 \\
\hline ROA & -0.254 & 0.195 & $0.000 * * *$ \\
\hline GROWTH & 0.091 & $\mathbf{0}$ & 0.101 \\
\hline
\end{tabular}

\section{Panel B: Stock Price Equation}

$\mathrm{Sp}=\mathrm{b}_{0}+\mathrm{b}_{1} \mathrm{EQ}+\mathrm{b}_{2} \mathrm{SIZE}+\mathrm{b}_{3} \mathrm{LEV}+\mathrm{b}_{4} \mathrm{MB}+\varepsilon_{2}$

Standardized Standard

coefficient error

p-value 
The Relationship between Corporate Ownership Structure and

Ayah Ahmed Mohsen Mohamed

\begin{tabular}{lrcc}
\hline & & & \\
\hline Intercept & -171.46 & 75.321 & $0.023 * *$ \\
EQ & -0.192 & 16.121 & $0.000 * * *$ \\
SIZE & 0.109 & 3.581 & $0.047 * *$ \\
LEV & 0.165 & 24.192 & $0.003 * * *$ \\
MB & 0.337 & 1.442 & $0.000 * * *$ \\
\hline
\end{tabular}

Note: $* * *$ And $* *$ Represent significance at the 1 percent, and 5 percent levels, respectively.

As shown in Table 3.8, panel A, institutional ownership (INST) as well as managerial ownership (MGR) has a significant negative effect on the quality of reported earnings (EQ). The firm size (SIZE) has an insignificant positive effect on the quality of reported earnings (EQ). Return on assets (ROA) has a significant negative effect on the quality of reported earnings (EQ). The firm growth (GROWTH) has an insignificant positive effect on the quality of reported earnings.

Panel B of table 3.8 shows that the quality of reported earnings has a significant negative effect on the firm stock prices (SP). Besides the firm size (SIZE) has a significant positive effect on the firm stock prices. Further firm leverage (LEV) has a significant positive effect on the firm stock prices. Finally the market to book value ratio has a significant positive effect on the firm stock prices.

\section{Table 3.9:}

Standardized Total Effect, Direct Effect, and Indirect Effect

\begin{tabular}{cccc}
\hline & Total effect & Direct effect & $\begin{array}{c}\text { Indirect } \\
\text { effect }\end{array}$ \\
\hline INST & 0.023 & 0 & 0.023 \\
MGR & 0.046 & 0 & 0.046 \\
\hline
\end{tabular}


The Relationship between Corporate Ownership Structure and

Ayah Ahmed Mohsen Mohamed

As shown in table 5.12, institutional ownership (INST) as well as managerial ownership (MGR) has no direct effect on the firm stock prices however they have a significant positive indirect effect on the firm stock prices through its impact on the quality of reported earnings. The indirect effect of institutional ownership on the firm stock prices is composed of the negative direct effect (path coefficient $=-0.117$ ) of the level of institutional ownership on the quality of reported earnings and the direct negative effect (path coefficient $=-0.192$ ) from earnings quality to the firm stock prices. Combining the two paths results in a net positive indirect effect of $0.023(-0.117 *-0.192)$. The indirect effect of managerial ownership on the firm stock prices is composed of the negative direct effect (path coefficient $=-0.24$ ) of the level of managerial ownership on the quality of reported earnings and the direct negative effect (path coefficient $=-0.192$ ) from earnings quality to the firm stock prices. Combining the two paths results in a net positive indirect effect of $0.046(-0.24 *$ $0.192)$.

\section{Summary and Conclusion:}

Corporate ownership structure (i.e. identities of the firm equity holders and the size of their shareholdings) was widely perceived as a significant determinant of firm's objectives, shareholders' wealth and the extent of managerial opportunistic behavior, which implies that it could be a significant determinate of earnings quality as an important attribute of the financial reporting quality. 
The Relationship between Corporate Ownership Structure and

Ayah Ahmed Mohsen Mohamed

This study aims to examine the relationship between corporate ownership structure mainly the level of institutional as well as managerial ownership and the quality of reported. Besides this study aims to address the capital market consequences of the relationship between earnings quality and ownership structure by examining their impact on the firm stock price.

Using pooled ordinary least squares regression the study major findings were as follows: First, Institutional ownership (measured as the percentage of shares held by insurance companies, pension funds, investment trusts, and financial institutions) has a significant negative impact on the quality of reported earnings thereby, supporting $\mathbf{H}_{\mathbf{1}}$ which suggests that even though the monitoring mechanisms associated with institutional ownership are perceived as generally positive, higher level of institutional ownership may be perceived to lead to more self-interested behavior on the part of institutions which ultimately negatively influence the quality of reported earnings.

Second, Managerial ownership (percentage of outstanding shares held by executive directors and the board members) has a significant negative impact on the quality of reported earnings thereby supporting $\mathbf{H}_{\mathbf{1 b}}$ which suggests that greater insider ownership (i.e. managerial ownership) has an entrenchment effect where controlling shareholders possess sufficient power to act on their self interest and expropriate private benefits at the expense of minority shareholders. Such self interest behavior 
The Relationship between Corporate Ownership Structure and

Ayah Ahmed Mohsen Mohamed

may induce corporate managers to engage in earnings manipulation practices that have a direct wealth effect for the management while on the other hand could ultimately negatively influence the quality of reported earnings. One possible explanation for such an entrenchment effect could be the reduction in discipline from external sources such as the managerial labor market and market for corporate control (i.e. takeover market).

Third, the quality of reported earnings has a significant negative impact on the firm stock prices which is inconsistent with $\mathbf{H}_{2}$ thereby suggesting that outside investors most commonly might not recognize and respond to the presence of earnings manipulations the erodes the quality of reported earnings, which ultimately leads to a significant security mispricing.

Using path analysis to test the indirect effect of corporate ownership structure on the firm stock prices through its impact on earnings quality, the results has shown that institutional ownership has a significant positive indirect effect on the firm stock prices through its impact on the quality of reported earnings which is inconsistent with $\mathbf{H}_{\mathbf{3} \mathbf{a}}$. Managerial ownership as well has a significant positive indirect effect on the firm stock prices through its impact on the quality of reported earnings which is inconsistent with $\mathbf{H}_{\mathbf{3} \mathbf{b}}$. Thereby these results suggests that the capital market do not incorporate the effect of potential expropriation by entrenched institutional shareholders as well as insiders, in pricing corporate securities. 
The Relationship between Corporate Ownership Structure and

Ayah Ahmed Mohsen Mohamed

Overall this study contributes to extent literature addressing the relationship between various corporate governance mechanisms and the financial reporting quality by focusing on the monitoring role of institutional investors as well as managerial ownership of equity and their impact on the quality of reported earnings as one major dimension of the financial reporting quality. Further this study extends prior literature by addressing the capital market consequences of the relationship between corporate ownership structure and earnings quality.

\section{Recommendations:}

i. Future research could employ other accrual quality models that could potentially overcome the limitations of the Dechow and Dichev model; one major limitation of their model is that it cannot be used to identify distortions induced by long-term accruals. This is an important limitation of the model because impairments of PPE and goodwill are likely to reflect earnings management or accounting distortions that can be particularly important for evaluating the quality of earnings.

ii. Other accrual quality models could be applied on an industry bases so that further research could identify different earnings management patterns in each industry.

iii. Further research could concentrate on the influence of other aspects of shareholders identities (for instance family ownership) on earnings quality over a longer period of time. 
The Relationship between Corporate Ownership Structure and

$\sim$ Ayah Ahmed Mohsen Mohamed

i. Further research could potentially focus on public versus private ownership of equity and its influence on the quality of reported earnings using a sample that is comprised of both public and privately held firms. 
The Relationship between Corporate Ownership Structure and

Ayah Ahmed Mohsen Mohamed

\section{References:}

Ball, R., \& Shivakumar, L. (2005). Earnings quality in UK private firms: comparative loss recognition timeliness. Journal of Accounting and Economics, 39, 83-128.

Ball, R., Robin, A., \& Wu, J. S. (2003). Incentives versus standards: properties of accounting income in four East Asian countries. Journal of Accounting and Economics, 36(1-3), 235-270.

Balsam, S., Bartov, E., \& Marquardt, C. (2002). Accruals Management, Investor Sophistication, and Equity Valuation: Evidence from 10-Q Filings. Journal of Accounting Research, 40(4), 987-1012.

Callen, J. L., Khan, M., \& Lu, H. (2013). Accounting Quality, Stock Price Delay, and Future Stock Returns. Contemporary Accounting Research, 30(1), 269-295.

Christensen, H. B., Lee, E., \& Walker, M. (2008, March). Incentives or standards: What determines accounting quality changes around IFRS adoption?. Working paper, University of Chicago.

Chung, R., Firth, M., \& Kim, J. B. (2002). Institutional monitoring and opportunistic earnings management. Journal of Corporate Finance, 8(1), 29-48.

Dechow, P. M., \& Dichev, I. D. (2002). The Quality of Accruals and Earnings: The Role of Accrual Estimation Errors. The Accounting Review, 77, 35-59.

Dechow, P., Ge , W., \& Schrand, C. (2010). Understanding earnings quality : A review of the proxies, their determinants and their consequences. Journal of Accounting and Economics, 50, 344-401.

Fan, J. P., \& T.J. Wong. (2002). Corporate ownership structure and the informativeness of accounting earnings in east asia. Journal of Accounting and Economics, 401-425.

Francis, J., Schipper, K., \& Vincent, L. (2005). Earnings and dividend informativeness when cash flow rights are separated from voting rights. Journal of Accounting and Economics, 39, 329-360. 
The Relationship between Corporate Ownership Structure and

Ayah Ahmed Mohsen Mohamed

Gabrielsen, G., Gramlich, J. D., \& Plenborg, T. (2002). Managerial Ownership, Information Content of Earnings, and Discretionary Accruals in a Non-US Setting. Journal of Business Finance \& Accounting, 29(7-8), 967-988.

Hope, O.-K., Thomas, W. B., \& Vyas, D. (2013). Financial Reporting Quality of U.S. Private and Public Firms. Accounting Review, 88(5), 1715-1742.

Houqe, M. N., Zijl, T. v., Dunstan, K., \& Karim, A. W. (2012). The Effect of IFRS Adoption and Investor Protection on Earnings Quality Around the World. The International Journal of Accounting, 47, 333-355.

Kasznik, R., \& Mcnichols, M. F. (2002). Does Meeting Earnings Expectations Matter? Evidence from Analyst Forecast Revisions and Share Prices. Journal of Accounting Research, 40(3), 727-759.

Kline, T. J., \& Klammer, J. D. (2001). Path Model Analyzed With Ordinary Least Squares Multiple Regression Versus LISREL. Journal of Psychology, 135(2), 213-225.

Koh, P. S. (2003). On the association between institutional ownership and aggressive corporate earnings management in Australia. The British Accounting Review, 35(2), 105-128.

Koh, P.-S. (2007). Institutional investor type, earnings management and benchmark beaters. Journal of Accounting and Public Policy, 267299.

Lee, C.-W. J., Li, L. Y., \& Yue, H. (2006). Performance, Growth and Earnings Management. Review of Accounting Studies, 11(2-3), 305334.

Ogneva, M. (2012). Accrual Quality, Realized Returns, and Expected Returns: The Importance of Controlling for Cash Flow Shocks. The Accounting Review, 87(4), 1415-1444.

Soderstrom, N. S., \& Sun, K. J. (2007). IFRS adoption and accounting quality: A review. European Accounting Review, 16, 675-702. 
Srinidhi, B. N., \& Gul, F. A. (2007). The Differential Effects of Auditors' Nonaudit and Audit Fees on Accrual Quality. Contemporary Accounting Research, 24(2), 595-629.

Velury, U., \& Jenkins, D. (2006). Institutional ownership and the quality of earnings. Journal of Business Research, 59, 1043-1051.

Wang, D. (2006). Founding Family Ownership and Earnings Quality. Journal of Accounting Research, 44(3), 619-656.

Warfield, T. D., Wild, J. J., \& Wild, K. L. (1995). Managerial ownership, Accounting Choices, and Informativness of Earnings. Journal of Accounting and Ecnomices, 20(1), 61-91.

Yeo, G., Tan, P., Ho, K., \& Chen, S. (2002). Corporate Ownership Structure and the Informativeness of Earnings. Journal of Business Finance \& Accounting, 29(7-8), 1023-1046. 